NASA/TM-2006-214246

\title{
Experimental and Computational Analysis of Unidirectional Flow Through Stirling Engine Heater Head
}

Scott D. Wilson

Sest, Inc., Middleburg Heights, Ohio

Rodger W. Dyson and Roy C. Tew

Glenn Research Center, Cleveland, Ohio

Rikako Demko

Sest, Inc., Middleburg Heights, Ohio 


\section{NASA STI Program . . . in Profile}

Since its founding, NASA has been dedicated to the advancement of aeronautics and space science. The NASA Scientific and Technical Information (STI) program plays a key part in helping NASA maintain this important role.

The NASA STI Program operates under the auspices of the Agency Chief Information Officer. It collects, organizes, provides for archiving, and disseminates NASA's STI. The NASA STI program provides access to the NASA Aeronautics and Space Database and its public interface, the NASA Technical Reports Server, thus providing one of the largest collections of aeronautical and space science STI in the world. Results are published in both non-NASA channels and by NASA in the NASA STI Report Series, which includes the following report types:

- TECHNICAL PUBLICATION. Reports of completed research or a major significant phase of research that present the results of NASA programs and include extensive data or theoretical analysis. Includes compilations of significant scientific and technical data and information deemed to be of continuing reference value. NASA counterpart of peer-reviewed formal professional papers but has less stringent limitations on manuscript length and extent of graphic presentations.

- TECHNICAL MEMORANDUM. Scientific and technical findings that are preliminary or of specialized interest, e.g., quick release reports, working papers, and bibliographies that contain minimal annotation. Does not contain extensive analysis.

- CONTRACTOR REPORT. Scientific and technical findings by NASA-sponsored contractors and grantees.
- CONFERENCE PUBLICATION. Collected papers from scientific and technical conferences, symposia, seminars, or other meetings sponsored or cosponsored by NASA.

- SPECIAL PUBLICATION. Scientific, technical, or historical information from NASA programs, projects, and missions, often concerned with subjects having substantial public interest.

- TECHNICAL TRANSLATION. Englishlanguage translations of foreign scientific and technical material pertinent to NASA's mission.

Specialized services also include creating custom thesauri, building customized databases, organizing and publishing research results.

For more information about the NASA STI program, see the following:

- Access the NASA STI program home page at http://www.sti.nasa.gov

- E-mail your question via the Internet to help@sti.nasa.gov

- Fax your question to the NASA STI Help Desk at 301-621-0134

- Telephone the NASA STI Help Desk at 301-621-0390

- Write to:

NASA STI Help Desk

NASA Center for AeroSpace Information 7121 Standard Drive Hanover, MD 21076-1320 
NASA/TM-2006-214246

AIAA-2005-5539

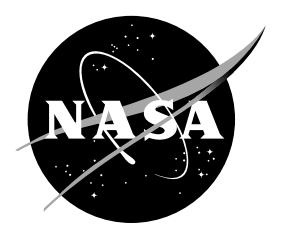

\section{Experimental and Computational Analysis of Unidirectional Flow Through Stirling Engine Heater Head}

Scott D. Wilson

Sest, Inc., Middleburg Heights, Ohio

Rodger W. Dyson and Roy C. Tew

Glenn Research Center, Cleveland, Ohio

Rikako Demko

Sest, Inc., Middleburg Heights, Ohio

Prepared for the

Third International Energy Conversion Engineering Conference

sponsored by the American Institute of Aeronautics and Astronautics

San Francisco, California, August 15-18, 2005

National Aeronautics and

Space Administration

Glenn Research Center

Cleveland, Ohio 44135 


\section{Acknowledgments}

This work was performed for the Radioisotope Power System (RPS) Program at NASA Headquarters, which provided support for this effort, and was supported by the NASA Glenn Research Center Contract NAS3-03064.

This report is a formal draft or working paper, intended to solicit comments and ideas from a technical peer group.

This report contains preliminary findings, subject to revision as analysis proceeds.

Trade names and trademarks are used in this report for identification only. Their usage does not constitute an official endorsement, either expressed or implied, by the National Aeronautics and Space Administration.

Level of Review: This material has been technically reviewed by technical management.

Available from

NASA Center for Aerospace Information 7121 Standard Drive

Hanover, MD 21076-1320
National Technical Information Service 5285 Port Royal Road Springfield, VA 22161 


\title{
Experimental and Computational Analysis of Unidirectional Flow Through Stirling Engine Heater Head
}

\author{
Scott D. Wilson \\ Sest, Inc. \\ Middleburg Heights, Ohio 44130 \\ Rodger W. Dyson and Roy C. Tew \\ National Aeronautics and Space Administration \\ Glenn Research Center \\ Cleveland, Ohio 44135 \\ Rikako Demko \\ Sest, Inc. \\ Middleburg Heights, Ohio 44130
}

\begin{abstract}
A high efficiency Stirling Radioisotope Generator (SRG) is being developed for possible use in long-duration space science missions. NASA's advanced technology goals for next generation Stirling convertors include increasing the Carnot efficiency and percent of Carnot efficiency. To help achieve these goals, a multi-dimensional Computational Fluid Dynamics (CFD) code is being developed to numerically model unsteady fluid flow and heat transfer phenomena of the oscillating working gas inside Stirling convertors. In the absence of transient pressure drop data for the zero mean oscillating multi-dimensional flows present in the Technology Demonstration Convertors on test at NASA Glenn Research Center, unidirectional flow pressure drop test data is used to compare against 2D and 3D computational solutions. This study focuses on tracking pressure drop and mass flow rate data for unidirectional flow though a Stirling heater head using a commercial CFD code (CFD-ACE). The commercial CFD code uses a porous-media model which is dependent on permeability and the inertial coefficient present in the linear and nonlinear terms of the Darcy-Forchheimer equation. Permeability and inertial coefficient were calculated from unidirectional flow test data. CFD simulations of the unidirectional flow test were validated using the porous-media model input parameters which increased simulation accuracy by 14 percent on average.
\end{abstract}

\section{Nomenclature}

\section{Latin letters and Abbreviations}

$A_{\text {app }} \quad$ regenerator approach area

$A_{\text {eff }} \quad$ effective area

$C_{D} \quad$ Darcy Friction Factor

$C_{f} \quad$ porous-media inertial coefficient

$d_{h} \quad$ hydraulic diameter

$d_{w} \quad$ wire diameter

$f_{D} \quad$ three-parameter modified-Ergun equation

$K \quad$ porous-media permeability coefficient

$L \quad$ regenerator length

$\dot{m} \quad$ mass flow rate

$p \quad$ porosity or void volume

$P \quad$ pressure

Re Reynolds number

$r^{2} \quad$ coefficient of determination

$T$ temperature

$u \quad$ stream wise velocity

1D one-dimmensional

2D two-dimmensional

3D three-dimmensional
Greek letters

$\Delta \quad$ change

$\alpha \quad$ correlation constant

$\beta \quad$ correlation constant

$\gamma \quad$ correlation constant

$\rho$ density, $\mathrm{kg} / \mathrm{m}^{3}$

$\mu \quad$ dynamic viscosity, $\mathrm{kg} / \mathrm{m}-\mathrm{s}$

\begin{tabular}{ll}
\multicolumn{2}{l}{ Subscripts } \\
atm & atmosphere \\
$k$ & cooler \\
$d$ & downstream \\
$h$ & heater \\
$r$ & regenerator \\
$s$ & solid \\
$u$ & upstream
\end{tabular}




\section{Introduction}

High-efficiency Stirling Radioisotope Generators (SRGs) are being developed for potential NASA space science missions. The SRG 110 is being developed by the Department of Energy, Lockheed Martin, Infinia (formerly Stirling Technology Company) and NASA Glenn Research Center (GRC) for possible future use, including electric power for unmanned Mars rovers and deep space missions (refs. 1 and 2). The SRG 110 is expected to have a system efficiency of about 22 percent and a specific power of about $4 \mathrm{~W}_{\mathrm{e}} / \mathrm{kg}$. The high SRG 110 efficiency would reduce the amount of required radioisotope by a factor of four or more compared to currently-used Radioisotope Thermoelectric Generators. In addition, projections for advanced technology development have been established for future Stirling radioisotope power systems. These goals include achieving 8 to $10+\mathrm{W}_{\mathrm{e}} / \mathrm{kg}$ specific power and 30 to 35 percent system efficiency.

To help achieve these goals, a multi-dimensional Computational Fluid Dynamics (CFD) code is being developed to numerically model unsteady fluid flow and heat transfer phenomena of the oscillating working gas inside the Stirling cycle (ref. 3). The commercial codes being used, CFD-ACE and Fluent, provide a macroscopic porous-media model (includes linear and nonlinear terms for pressure drop as a function of velocity) where permeability, inertial coefficient, and porosity are required input parameters. Transient pressure drop data is not commonly available between the compression-space and expansion-space of the Technology Demonstration Convertor (TDC). In the absence of pressure drop measurements for oscillating flow conditions, unidirectional flow test data has been used to compare against CFD solutions for simulations of unidirectional flow through the test assembly (includes test fixture and heater head). By assuming quasi-steady flow (refs. 8 and 10), the unidirectional flow test data was used to calculate the porous-media input parameters (permeability and inertial coefficient) for use in the oscillating flow CFD simulations. This effort involved reducing the unidirectional flow test data, calculating permeability and inertial coefficient, and validating CFD models using the calculated porous-media input parameters.

\section{Unidirectional Flow Testing}

Since the first version of the TDC was delivered to GRC, improvements have been made to the overall design. There is interest in understanding how those changes, particularly in the heat exchanger (HX) circuit, affect pressure drop between the expansion-space and compression-space of the Stirling engine. The HX circuit includes the heater, regenerator, and cooler, but the main interest is the pressure drop across the regenerator. The regenerator accounts for approximately 95 percent of the pressure drop across the TDC HX circuit according to Sage TDC simulations for oscillating helium (ref. 5), and approximately 90 percent of the pressure drop across the TDC HX circuit according to Sage TDC simulations for oscillating air at a reference operating point where the operating frequency is $80 \mathrm{~Hz}$, heater temperature is $650{ }^{\circ} \mathrm{C}$, cooler temperature is $80^{\circ} \mathrm{C}$, and mean operating pressure is 25 bar. The purpose of this test was to measure pressure drop across the HX circuit of a TDC heater head as a function of unidirectional mass flow rate. Unidirectional air flow was introduced to a TDC heater head and mass flow rate, local pressure, and local temperature were measured at opposite ends of the HX circuit.

\section{A. Test Fixture Design}

A proposed flow test fixture design was simulated with a 2D axisymmetric CFD model (fig. 1, right) for flow into the off-center test fixture port and reversed flow into the center port. Figure 1 (left) shows a 3D computer aided drafting (CAD) model and the corresponding CFD simulation with velocity gradients shown. According to the 2D axisymmetric results for the proposed geometry and initial inlet flow rate, the velocity profile did not fully develop for flow through the approach annulus. Flow in the reverse direction did not result in any undesirable flow gradients. Based on the CFD simulation results, the flow fixture design was revised. The design revision included an adjustment to the entrance geometry, an adjustment to the approach annulus radial location, and the addition of a flow distribution screen near the heater head interface. A 3D truncated domain of the entrance region near the offcenter port was simulated to confirm improved velocity distribution as seen in appendix figure A-3 (left). The fabricated test fixture and attached heater head can be seen in figure 2 . 


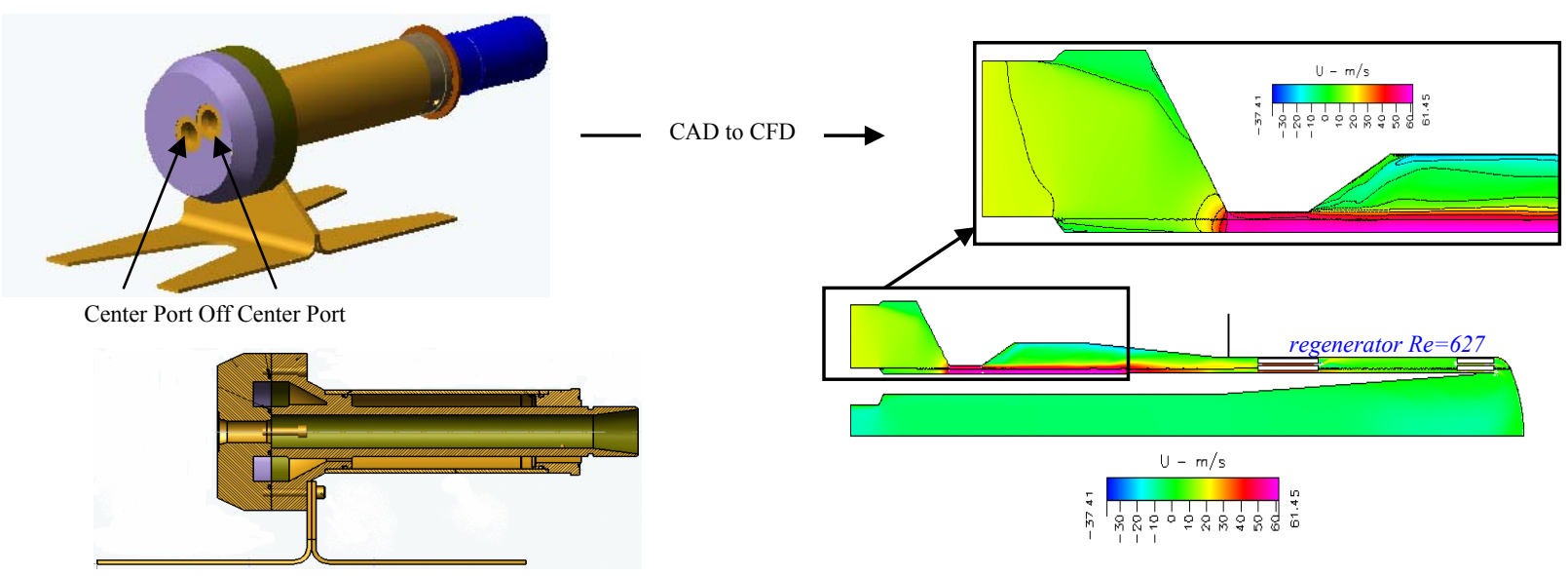

Figure 1.-CAD and CFD Models. CFD simulations prompted unidirectional flow test fixture design revisions.

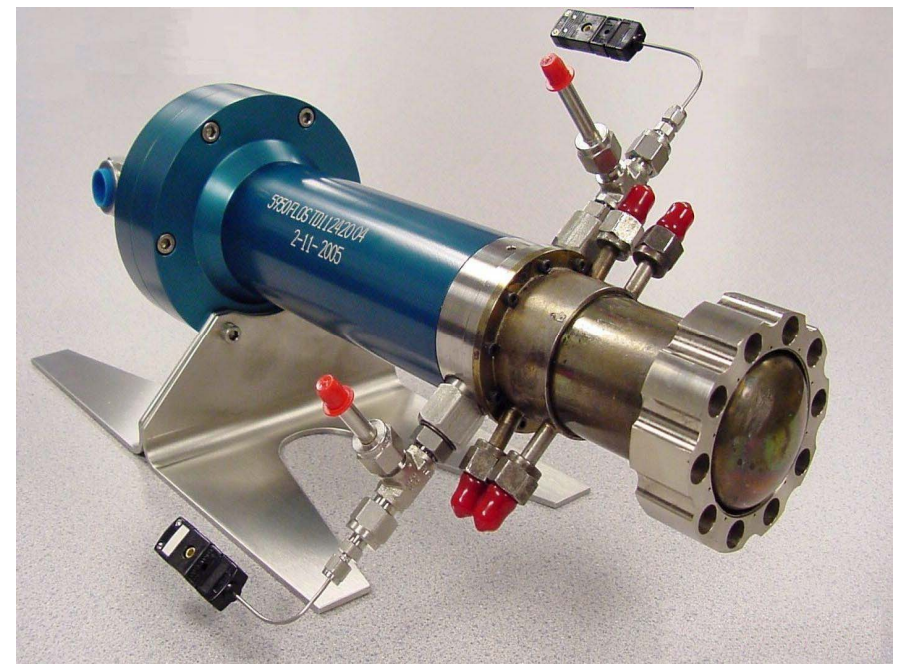

Figure 2.- Unidirectional flow test fixture assembly.

\section{B. Unidirectional Flow Test Conditions and Results}

The purpose of the unidirectional flow test was to characterize TDC heater head pressure drop as a function of mass flow rate. Pressure drop across the TDC heat exchanger circuit was estimated using Sage 1D oscillating flow simulation for air oscillating at the reference operating point. The resulting $41 \mathrm{kPa}$ pressure drop across the HX circuit was used as the test target pressure drop. This pressure drop corresponds to a range of regenerator Reynolds numbers ( 0 to 100 ) commonly observed in $1 \mathrm{D}$ and $3 \mathrm{D}$ oscillating flow computational solutions at the reference operating point. The GRC Flow Calibration Laboratory (FCL) facility gas supply and sonic nozzle were originally sized from estimated mass flow rates derived from the 1D oscillating flow simulations. Preliminary testing included a flow bench capacity test. The mass flow rate reached a maximum capacity corresponding to a pressure drop across the $\mathrm{HX}$ circuit equal to $36 \mathrm{kPa}$, which was accepted as a maximum pressure drop for the test. A leak check was performed by applying $34.5 \mathrm{kPa}$ to the closed test section. The test conditions for each of the two flow directions are summarized in table I.

TABLE I.-FLOW TEST CONDITIONS

\begin{tabular}{|c|c|c|c|c|c|c|c|}
\hline $\begin{array}{c}\text { Flow } \\
\text { direction }\end{array}$ & Data points & Inlet port & P upstream & T upstream & $\dot{m}$ upstream & T downstream & P downstream \\
\hline 1 & 20 & Center & measured & measured $*$ & Incremental & measured* & measured* $^{*}$ \\
\hline 2 & 20 & Off-center & measured & measured & Incremental & measured* & measured $^{*}$ \\
\hline
\end{tabular}

*atmospheric conditions 


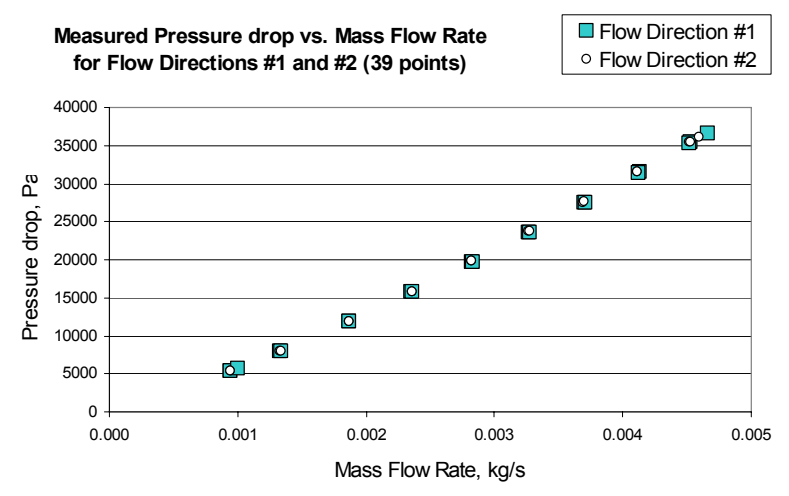

Figure 3.-Flow Test Results. Pressure drop versus mass flow rate for all test data points (39).

Air was introduced in increasing mass flow rates while pressure and temperature were measured upstream and downstream. For both flow directions, the mass flow rate was increased over 10 increments, then decreased over approximately the same 10 increments. The test section includes the TDC HX circuit (including the heater, regenerator, and cooler). Figure 3 shows the measured pressure drop versus mass flow rate for all data points (both flow directions). The variability of pressure drop for opposing flow directions was very small with an average difference of 0.24 percent. The maximum pressure drop and corresponding mass flow rate reached during the entire test was $36,635 \mathrm{~Pa}$ and $4.664 \mathrm{E}-03 \mathrm{~kg} / \mathrm{s}$ respectively. The upstream to downstream pressure ratio ranged from 0.73 to 0.95 indicating that the flow was not choked (choked flow pressure ratio $<0.528$ ) during the test according to steady 1D compressible flow theory (ref. 11).

\section{Permeability and Inertial Coefficient}

The porous medium permeability and inertial coefficient are needed for the ongoing Stirling CFD modeling effort. The commercial codes being used, CFD-ACE and Fluent, provide a macroscopic porous-media model (includes linear and nonlinear terms for pressure drop as a function of velocity) where permeability, inertial coefficient, and porosity are required input parameters. By assuming quasi-steady flow (refs. 8 and 10), the unidirectional flow test data was used to calculate the porous-media input parameters for use in current Stirling engine CFD simulations. The data presented in the previous section were reduced to calculate the porous-media input parameters using a method derived by Tew (ref. 4). In this derivation, Darcy's Equation, equation (1), expresses the pressure gradient as a function of the square of the flow field velocity.

$$
\frac{\Delta P}{L}=\frac{C_{D}}{d_{h}} \frac{1}{2} \rho u^{2}
$$

The hydraulic diameter, equation (2), for a porous medium is defined as a function of wire diameter and void volume.

$$
d_{h}=\frac{p}{1-p} d_{w}
$$

Rearranging equation (1) gives the Darcy Friction Factor, equation (3), which is proportional to the pressure drop as the flow field velocity varies.

$$
C_{D}=\frac{\Delta P}{L} \frac{2 d_{h}}{\rho u^{2}}
$$

The Darcy-Forchheimer Equation, equation (4), represents pressure drop through a porous medium as a function of operating state, system mass flow rate, and porous-media physical constants; permeability and inertial coefficient. 


$$
\frac{\Delta P}{L}=\frac{\mu}{K} u+\frac{C_{f}}{\sqrt{K}} \rho u^{2}
$$

The three-parameter modified-Ergun equation, equation (5), was employed by Gedeon and Wood as a regression function used to fit the Darcy friction factor calculated from oscillating flow data (ref. 6).

$$
f_{D}=\frac{\alpha}{\operatorname{Re}}+\beta \operatorname{Re}^{\gamma}
$$

In this derivation, the Darcy Friction Factor is approximately equal to the modified-Ergun equation. The regression function $f_{D}$ is substituted into equation (1) and (4) which can be seen in equation (9).

$$
C_{D}=f_{D}
$$

The Reynolds number for bulk fluid flow through the porous medium can be seen in equation (7).

$$
\operatorname{Re}=\frac{\dot{m} d_{h}}{\mu A_{\text {eff }}}
$$

The effective area of the porous medium, equation (8) is a function of the approach area and the void volume.

$$
A_{\text {eff }}=A_{\text {app }} p
$$

Tew used previous definitions to derive the porous-media permeability and inertial coefficient. By equating equation (1) and (4) and substituting the regression function $\left(f_{D}\right)$ for the Darcy friction factor $\left(\mathrm{C}_{D}\right)$, equation (9) can be separated into two parts.

$$
\underbrace{\frac{\mu}{K} u+\frac{C_{f}}{\sqrt{K}} \rho u^{2}=\frac{\alpha}{\operatorname{Re} \frac{1}{2 d_{h}} \rho u^{2}+\beta \operatorname{Re}^{\gamma} \frac{1}{2 d_{h}} \rho u^{2}}}_{\text {solve for } K}
$$

This derivation enables the grouped terms to be solved separately for permeability, equation (10), and the inertial coefficient, equation (11).

$$
\begin{gathered}
K=2 \frac{d_{h}^{2}}{\alpha} \\
C_{f}=\frac{\beta \mathrm{Re}^{\gamma}}{\sqrt{2 \alpha}}
\end{gathered}
$$

Figure 4 shows a stacked screen regenerator test section used in unidirectional and oscillating flow testing at the University of Minnesota (UMN) where heat transfer data is collected. The test section was designed for dynamic similarity with flow through a reference engine regenerator (refs. 8 to 10). Permeability and inertial coefficient, shown in table II, have been calculated using the three-parameter modified-Ergun equation based on data from the UMN large-scale stacked screen test section, the Sunpower oscillating flow test rig developed under SBIR NAS324396, and the GRC TDC heater head unidirectional flow test fixture (refs. 4 and 6). The shaded values have been investigated and are discussed later in this paper. 


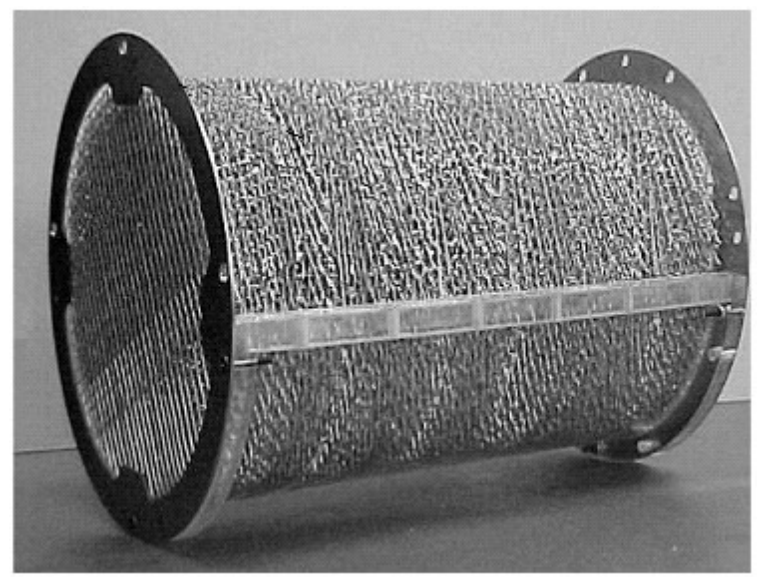

Figure 4.- Stacked Screen Regenerator Test Section. Unidirectional and oscillating flow testing conducted at the University of Minnesota where heat transfer data is collected. Examples of reduced data include thermal dispersion, velocity flow fields, permeability, inertial coefficient, etc.

TABLE II.-PERMEABILITY AND INERTIAL COEFFICIENT OBTAINED FROM TEST DATA

\begin{tabular}{|c|c|c|c|c|c|c|}
\hline \multirow[t]{2}{*}{ Coefficient } & \multicolumn{2}{|c|}{$\begin{array}{l}\text { UMN large-scale screen test } \\
\text { section ( } 90 \text { percent porosity) }\end{array}$} & \multicolumn{2}{|c|}{$\begin{array}{l}\text { Sunpower oscillating flow test rig } \\
\text { regenerator test samples }\end{array}$} & \multicolumn{2}{|c|}{$\begin{array}{c}\text { GRC unidirectional flow test fixture, } \\
\text { TDC heater head HX circuit }\end{array}$} \\
\hline & 1 & 2 & 3 & 4 & 5 & 6 \\
\hline & UMN 2003 & UMN 2004 & Woven screens & Metal felts & $100 \% \Delta \mathrm{P}^{f}$ & $90.2 \% \Delta \mathrm{P}^{\dagger}$ \\
\hline $\mathrm{K}, \mathrm{m}^{2}$ & $1.07 \mathrm{E}-07$ & $1.86 \mathrm{E}-07$ & $8.24 \mathrm{E}-07$ & $4.08 \mathrm{E}-10$ & $3.13 \mathrm{E}-10$ & $3.52 \mathrm{E}-10$ \\
\hline $\mathrm{C}_{\mathrm{f}}$ & 0.049 & 0.052 & $\begin{array}{l}0.130(\operatorname{Re}=25), \\
0.110(\operatorname{Re}=100)\end{array}$ & $\begin{array}{l}0.190(\mathrm{Re}=25) \\
0.170(\mathrm{Re}=100)\end{array}$ & $\begin{array}{l}0.155(\operatorname{Re}=25) \\
0.124(\operatorname{Re}=50) \\
0.097(\operatorname{Re}=100)\end{array}$ & $\begin{array}{l}0.154(\operatorname{Re}=25), \\
0.121(\operatorname{Re}=50), \\
0.095(\operatorname{Re}=100)\end{array}$ \\
\hline
\end{tabular}

${ }^{\ddagger}$ Based on 100 percent of total measured pressure drop, ${ }^{\dagger}$ Based on 90.2 percent of total measured pressure drop.

\section{Data Reduction}

There are three heat exchangers present in the TDC heater head HX circuit (heater, regenerator, and cooler). The unidirectional flow test data represents pressure drop across the entire HX circuit (includes minor losses due to abrupt area changes in that HX circuit) whereas the porous-media model input parameters, permeability and inertial coefficient, are applied to only the CFD model regenerator volume. Sage and CFD simulations were used to estimate what percentage of the total pressure drop was contributed by the regenerator in order to calculate a pressure drop factor to be applied to the test data, seen in equation (12) and (13), before the Darcy friction factor was calculated.

$$
\begin{aligned}
& \frac{\Delta P_{\text {regenerator }}}{\Delta P_{\text {HXcircuit }}}=\left.0.975\right|_{C F D} \\
& \frac{\Delta P_{\text {regenerator }}}{\Delta P_{\text {HXcircuit }}}=\left.0.902\right|_{S A G E}
\end{aligned}
$$

The pressure drop factor decreases the measured pressure drop test data by the estimated fraction of regenerator pressure drop to HX circuit pressure drop. The CFD pressure drop factor was not used in the study because it was very close (within 2.5 percent) of the test data whereas the Sage pressure drop factor was applied to the measured pressure drop to explore a significant difference from the test data. Figure 5 shows a comparison between the Darcy friction factor regression function based on oscillating flow test data (Gedeon and Wood), 100 percent of the measured pressure drop from unidirectional flow test data, and 90.2 percent of the measured pressure drop from unidirectional flow test data. Permeability and inertial coefficient were calculated from all three regression functions. All three sets of permeability and inertial coefficient were used in simulations discussed in the domain selection study and mesh independence study. 


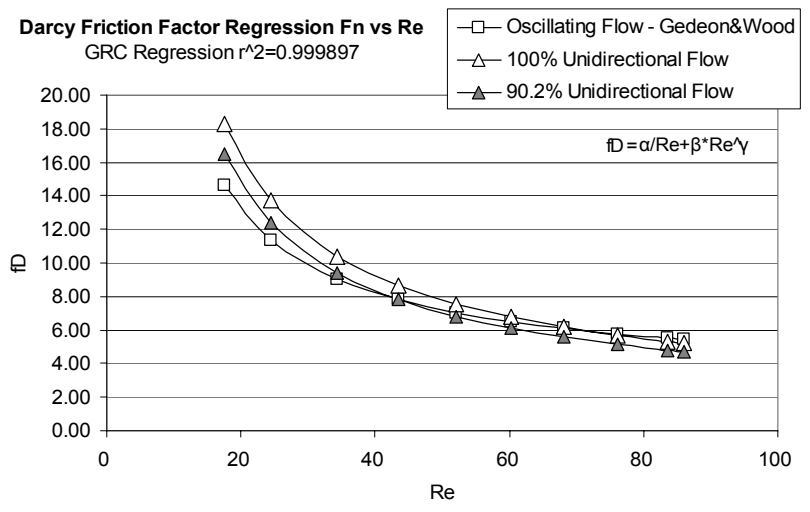

Figure 5.-Regression Function Comparison. Comparison between regression functions based on oscillating flow testing across regenerator sample and unidirectional flow testing (100 percent of total measured pressure drop and 90.2 percent of total measured pressure drop shown) across TDC heater head heat exchanger circuit.

Each regression function has a very high coefficient of determination indicating a good curve fit. appendix figure A-1 shows the Darcy friction factor regression function (three-parameter modified-Ergun equation), corresponding statistical residuals and coefficient of determination $\left(\mathrm{r}^{2}\right)$ for 100 percent of the total pressure drop measured in the unidirectional flow test based on all unidirectional flow test data points shown in figure 3. Similarly, appendix figure A-2 shows the Darcy friction factor regression function, corresponding statistical residuals and coefficient of determination for 90.2 percent of the total pressure drop measured in the unidirectional flow test.

As previously mentioned, Sage and CFD simulations were used to estimate what percentage of the total pressure drop was contributed by the regenerator. CFD simulation results for unidirectional air flow through the TDC heater head (containing annular HX fins, 2D approximation of 3D geometry) for a physical state equal to maximum pressure drop data point, seen in figure 3, resulted in approximately 35,766 Pa. Similarly, Sage simulation results for air oscillating in the TDC at the reference operating point resulted in a maximum pressure drop across the regenerator of approximately 37,000 Pa. The likely causes for the considerable difference in CFD results when compared to Sage results are: (a) that Sage calculates approximate pressure-drop/rise end effects using standard steady-flow expressions and CFD-ACE calculates pressure-drop/rise end effects using the full Navier Stokes equations for discretized domains and (b) the Sage simulated reference operating point mean pressure of 25 bar and the CFD simulated reference pressure of 1 bar differ by a factor of 25 .

\section{Computational Modeling and Analysis}

The purpose of the modeling effort was to track unidirectional flow test data in order to validate the derived permeability and inertial coefficient for use in the CFD simulations of unidirectional flow through the TDC heater head. Recall that the permeability and inertial coefficient are used as input parameters in the commercial CFD code porous-media model. The ongoing Stirling simulation effort stands to benefit from improved estimates of these coefficients. The quasi-steady flow assumption suggests that coefficients derived from unidirectional flow test data can be used in oscillating flow simulations. This assumption is based on the low Reynolds numbers found in regenerator flow. The unidirectional flow modeling effort consists of domain selection study, mesh independence study, and data tracking study.

\section{A. Physical Models}

Three domains were investigated simultaneously in order to select the most economical model able to produce reasonable results. Figures 6,7 , and 8 show three solution domains used for the domain selection. All models use 2D approximations for annular fin HXs based on the actual HX geometry. These 2D approximations minimize the approximation difference for hydraulic diameter, flow volume, and wetted surface when compared to the actual geometry. The 3D model was run in parallel on 4 processors to reduce simulation run time. Axial and circumferential velocity distribution can be seen in appendix figure A-3 (right) where velocity magnitude gradients suggest there is a non-uniform circumferential velocity distribution in the throttle. 


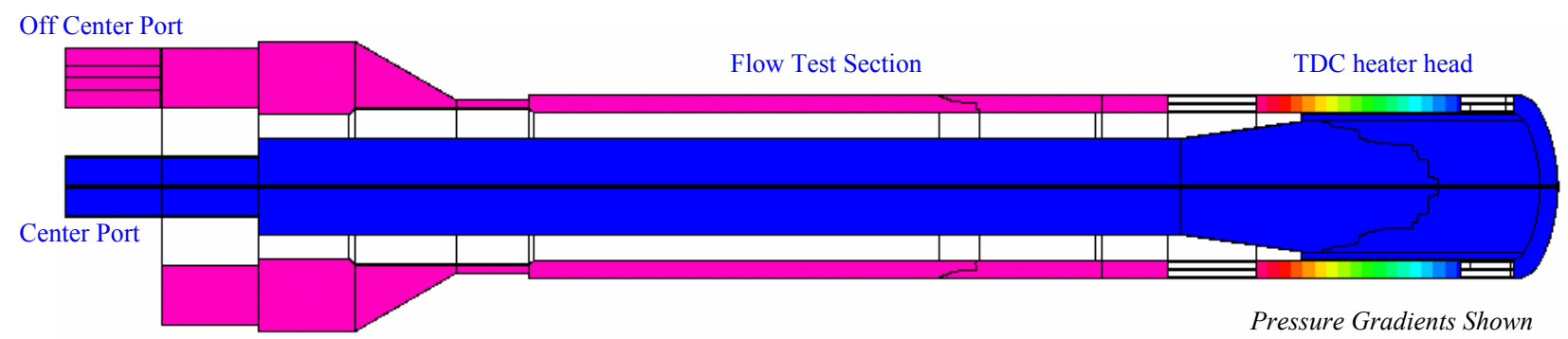

Figure 6.-Domain Selection. Model 1 (3D $180^{\circ}$ revolution of total domain, 2.44E +06 mesh cells) was used to determine the most economically suitable mesh during the Domain Selection Study.

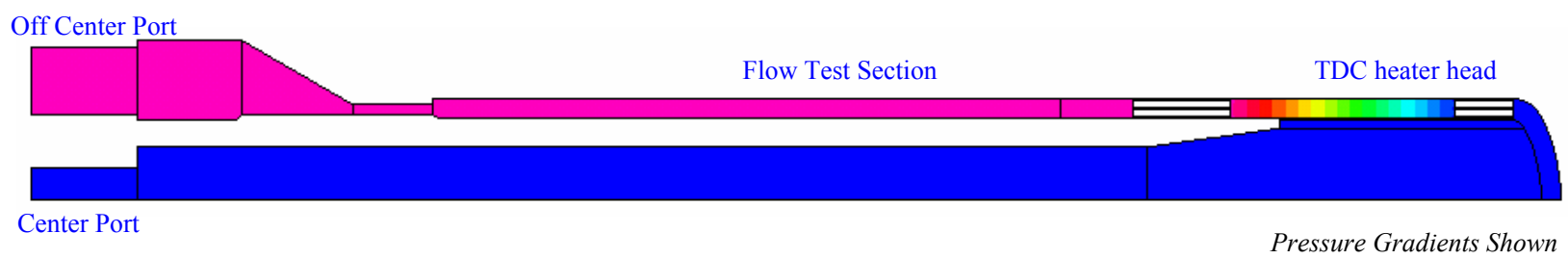

Figure 7.-Domain Selection. Model 2 (2D axisymmetric model of total domain, 1.86E+05 mesh cells) was used to determine the most economically suitable mesh during the Domain Selection Study.

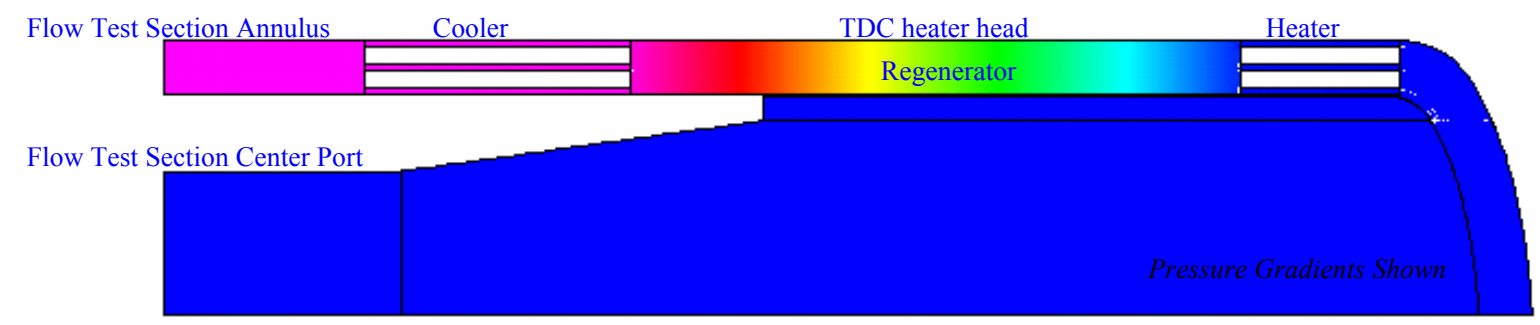

Figure 8.-Domain Selection. Model 3 (2D axisymmetric model of total domain, 1.11E+05 mesh cells) was used to determine the most economically suitable mesh during the Domain Selection Study.

\section{B. Flow Assumptions, Boundary Conditions, and Convergence}

The simulation results are dependent on the accuracy of the geometric representation of the test section, the boundary conditions, flow assumptions, and the corresponding closure given to those assumptions (SIMPLE pressurevelocity coupled in this case) (ref. 7). The flow assumptions and boundary conditions used to define the simulations are (a) no heat transfer (adiabatic at all non-flow external boundaries), (b) laminar flow, (c) constant density, constant viscosity, (d) constant porous-media physical properties, (e) thermal capacity in walls neglected, (f) downstream boundary conditions at constant pressure, and $(\mathrm{g})$ upstream boundary conditions at constant velocity. The simulation convergence criteria was set by the analyst to $<1$ percent of the system mass flow rate which was calculated taking the difference of the simulated inlet and outlet mass flow rate (per radian for axisymmetric models). It follows that adequate convergence at maximum flow rates for axisymmetric models was achieved at $<1.0 \mathrm{E}-07 \mathrm{~kg} / \mathrm{s} / \mathrm{rad}$. Likewise, adequate convergence at maximum flow rates for $3 \mathrm{D}$ models was achieved at $<4.6 \mathrm{E}-05 \mathrm{~kg} / \mathrm{s}$. 

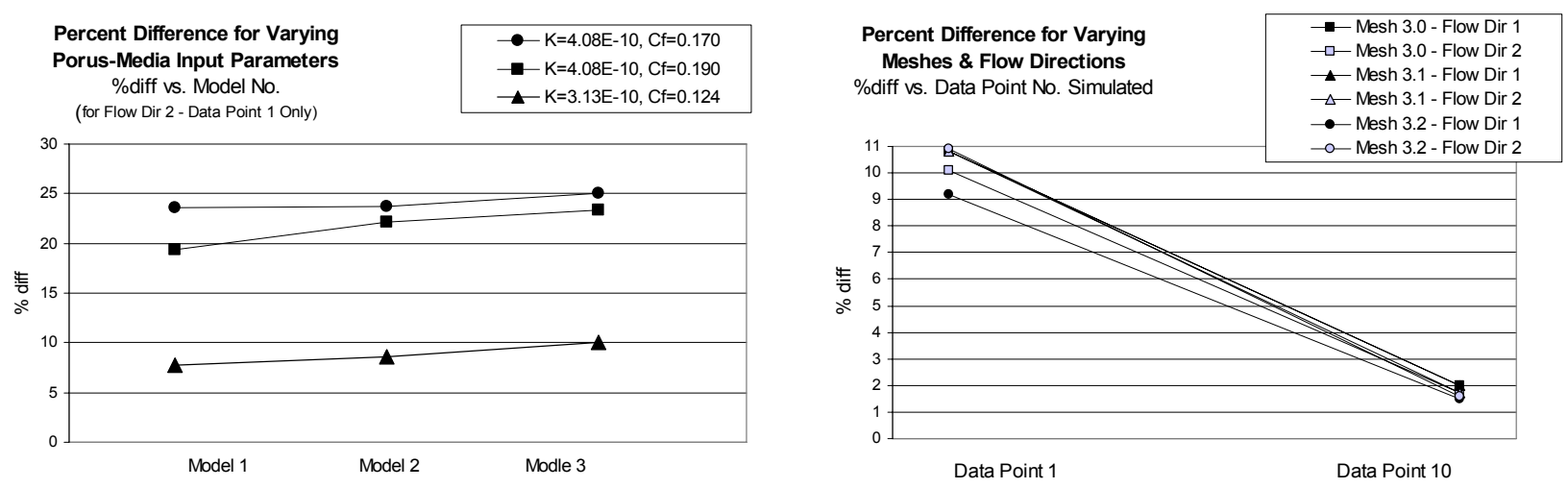

Figure 9.-Domain Selection Study Results and Mesh Independence Study Results. Percent difference for Models 1,2 , and 3 as porous-media input parameters vary (left), percent difference for Meshes 3.0, 3.1, and 3.2 as flow direction and data point vary (right).

\section{Domain Selection Study}

Simulations were performed to rate simulation run time and results accuracy based on a preliminary mesh for each domain. The results from the domain selection study based on preliminary meshes are shown in table III, where the description of the domain, corresponding mesh cell count, porous-media models input parameters, data point simulated, and results accuracy can be seen. The accuracy of the results did vary depending on the porous-media model input parameters used in the simulations. Figure 9 (left) shows that the highest accuracy was achieved by using the permeability and inertial coefficient derived from unidirectional flow data $(K=3.13 \mathrm{E}-10, C f=0.124)$. Definition of percent difference is shown in equation (14). Also, it can be seen that the more expensive models produced more accurate results. The trade off of accuracy for decreased simulation time encouraged the decision to choose Model 3 for the mesh independence study and subsequent data tracking effort.

$$
\% \text { diff }=100 \%-\frac{\operatorname{Min} \Delta P}{\operatorname{Max} \Delta P} 100 \%
$$

TABLE III.-DOMAIN SELECTION STUDY RESULTS

\begin{tabular}{|c|c|c|c|c|c|c|}
\hline Model & Model Description & $\mathrm{K}, \mathrm{m}^{2}$ & $\mathrm{C}_{f}$ & $\begin{array}{l}\text { Data point } \\
\text { simulated }^{*}\end{array}$ & $\begin{array}{c}\text { Data } \Delta \mathrm{P}, \\
\mathrm{Pa}\end{array}$ & $\begin{array}{c}\mathrm{CFD} \triangle \mathrm{P}, \mathrm{Pa} \\
(\% \text { diff })\end{array}$ \\
\hline \multirow[t]{4}{*}{1} & $3 \mathrm{D}, 180^{\circ}$ Revolution, total domain & $4.08 \mathrm{E}-10$ & 0.170 & FD2-DP1 & 5324 & $4068(23.6)$ \\
\hline & $2.44 \mathrm{E}+06$ mesh cells & $4.08 \mathrm{E}-10$ & 0.190 & FD2-DP1 & 5324 & $4290(19.4)$ \\
\hline & Simulation run time $=12 \mathrm{hrs}$ & & & & & \\
\hline & $\begin{array}{l}\text { Convergence: } 4.5 \mathrm{E}-06,(>99.99 \text { percent } \\
\mathrm{kg} / \mathrm{s})\end{array}$ & $3.13 \mathrm{E}-10$ & 0.124 & FD2-DP1 & 5324 & $4909(7.8)$ \\
\hline \multirow[t]{5}{*}{2} & 2D, axisymmetric, total domain & $4.08 \mathrm{E}-10$ & 0.170 & FD2-DP10 & 36076 & $31988(11.3)$ \\
\hline & $1.86 \mathrm{E}+05$ mesh cells & $4.08 \mathrm{E}-10$ & 0.190 & FD2,-P10 & 36076 & $32721(9.3)$ \\
\hline & Simulation run time $=3 \mathrm{hrs}$ & $4.08 \mathrm{E}-10$ & 0.170 & FD2-DP1 & 5324 & $4063(23.7)$ \\
\hline & $\begin{array}{l}\text { Convergence: } 4.9 \mathrm{E}-08,(>99.99 \text { percent } \\
\mathrm{kg} / \mathrm{s} / \mathrm{rad})\end{array}$ & $4.08 \mathrm{E}-10$ & 0.190 & FD2-DP1 & 5324 & $4147(22.1)$ \\
\hline & & $3.13 \mathrm{E}-10$ & 0.124 & FD2-DP1 & 5324 & $4866(8.6)$ \\
\hline \multirow[t]{4}{*}{3} & 2D, axisymmetric, truncated domain & $4.08 \mathrm{E}-10$ & 0.190 & FD2-DP10 & 36076 & $39890(9.6)$ \\
\hline & $1.11 \mathrm{E}+05$ mesh cells & $4.08 \mathrm{E}-10$ & 0.170 & FD2-DP1 & 5324 & $3986(25.1)$ \\
\hline & Simulation run time $=0.5 \mathrm{hr}$ & $4.08 \mathrm{E}-10$ & 0.190 & FD2-DP1 & 5324 & $4084(23.3)$ \\
\hline & $\begin{array}{l}\text { Convergence: } 8.9 \mathrm{E}-09,(>99.99 \text { percent } \\
\mathrm{kg} / \mathrm{s} / \mathrm{rad})\end{array}$ & $3.13 \mathrm{E}-10$ & 0.124 & FD2-DP1 & 5324 & $4785(10.1)$ \\
\hline
\end{tabular}

FDx, DPx: Flow Directions can be seen in table I and Data Points can be seen in figure 3. 


\section{Mesh Independence Study}

Simulations were performed to rate mesh sensitivity to flow physics based on a range of mesh cell counts for Model 3 in figure 8. The results from the mesh independence study are shown in table IV, where the description of the relative mesh cell count, porous-media models input parameters, data point simulated, and results accuracy can be seen. The minimum and maximum flow rates for each flow direction were simulated while the porous-media model input parameters were held constant.

The variation in the results as a function of mesh cell count was slight $(<2$ percent), varying more at lower flow rates. This indicated that the simulation results were nearly independent for all mesh cell counts. Mesh 3.0 was selected for the data tracking effort in order to minimize simulation run time with little difference in accuracy. Although Mesh 3.2 had a 20 percent lower mesh cell count compared to Mesh 3.0, it took longer to converge due to the need to under-relax the momentum equation to avoid divergence.

TABLE IV.-MESH INDEPENDENCE STUDY RESULTS

\begin{tabular}{|c|c|c|c|c|c|c|}
\hline Mesh & Model Description & $\mathrm{K}, \mathrm{m}^{2}$ & $\mathrm{C}_{f}$ & $\begin{array}{l}\text { Data Point } \\
\text { Simulated }\end{array}$ & $\begin{array}{c}\text { Data } \Delta \mathrm{P}, \\
\mathrm{Pa}\end{array}$ & $\begin{array}{l}\text { CFD } \Delta \mathrm{P}, \mathrm{Pa} \\
(\% \text { diff })\end{array}$ \\
\hline \multirow[t]{4}{*}{3.0} & $\begin{array}{l}\text { 2D, axisymmetric, truncated } \\
\text { domain }\end{array}$ & $3.13 \mathrm{E}-10$ & 0.124 & FD1-DP1 & 5328 & $4753(10.8)$ \\
\hline & $1.11 \mathrm{E}+05$ mesh cells (ref) & $3.13 \mathrm{E}-10$ & 0.124 & FD2-DP1 & 5324 & $4785(10.1)$ \\
\hline & Simulation run time $=0.5 \mathrm{hr}$ & $3.13 \mathrm{E}-10$ & 0.124 & FD1-DP10 & 36635 & $37393(2.0)$ \\
\hline & Convergence $=8.9 \mathrm{E}-07$ & $3.13 \mathrm{E}-10$ & 0.124 & FD2-DP10 & 36076 & $36689(1.7)$ \\
\hline \multirow[t]{6}{*}{3.1} & $\begin{array}{l}\text { 2D, axisymmetric, truncated } \\
\text { domain }\end{array}$ & $3.13 \mathrm{E}-10$ & 0.124 & FD1-DP1 & 5328 & $4751(10.8)$ \\
\hline & $1.43 \mathrm{E}+05$ mesh cells $(+22 \%)$ & $3.13 \mathrm{E}-10$ & 0.124 & FD2-DP1 & 5324 & $4748(10.8)$ \\
\hline & Simulation run time $=0.75 \mathrm{hr}$ & $3.52 \mathrm{E}-10$ & 0.121 & FD2-DP1 & 5324 & $4262(19.9)$ \\
\hline & Convergence $=8.1 \mathrm{E}-08$ & $3.13 \mathrm{E}-10$ & 0.124 & FD1-DP10 & 36635 & $37389(2.0)$ \\
\hline & & $3.13 \mathrm{E}-10$ & 0.124 & FD2-DP10 & 36076 & $36639(1.7)$ \\
\hline & & $3.52 \mathrm{E}-10$ & 0.121 & FD2-DP10 & 36076 & $33360(7.5)$ \\
\hline \multirow[t]{4}{*}{3.2} & $\begin{array}{l}\text { 2D, axisymmetric, truncated } \\
\text { domain }\end{array}$ & $3.13 \mathrm{E}-10$ & 0.124 & FD1-DP1 & 5328 & 4837 (9.2) \\
\hline & $8.92 \mathrm{E}+04$ mesh cells $(-20 \%)$ & $3.13 \mathrm{E}-10$ & 0.124 & FD2-DP1 & 5324 & $4746(10.9)$ \\
\hline & Simulation run time $=1.5 \mathrm{hr}$ & $3.13 \mathrm{E}-10$ & 0.124 & FD1-DP10 & 36635 & $37186(1.5)$ \\
\hline & Convergence $=3.9 \mathrm{E}-06$ & $3.13 \mathrm{E}-10$ & 0.124 & FD2-DP10 & 36076 & $36661(1.6)$ \\
\hline
\end{tabular}

*FDx, DPx: Flow Directions can be seen in table I and Data Points can be seen in figure 3.

Recall figure 5 which shows a comparison between Darcy friction factor regression functions for 90 and 100 percent of the measured pressure drop from unidirectional flow test data. Porous-media input parameters were calculated using the regression functions and are shown in table II, columns 5 and 6 . To investigate which set of porous-media input parameters increased the accuracy of the simulations, Mesh 3.1 was simulated using both sets of porous-media input parameters for the minimum and maximum pressure drop data points of flow direction 2 only. Simulation results using the porous-media input parameters calculated from 100 percent of the measured pressure drop from unidirectional flow test data were 7 percent more accurate on average when compared to simulation results using the porous-media input parameters calculated from the 90.2 percent of the measured pressure drop from unidirectional flow test data. The data points for each of the above mentioned simulations can be seen in table IV. Model 3 was rated best based on simulation run time and results accuracy criteria. Mesh 3.0 was rated best based on mesh sensitivity to flow physics criteria. The porous-media input parameters derived from 100 percent of the measured pressure drop from unidirectional flow test data were rated best based on results accuracy criteria.

Figure 10 shows the mesh selected for the data tracking effort. The mesh is a structured hexagonal grid where fine grids were used near walls to capture boundary layer flows. Smooth grid transition was ensured to avoid possible large gradients in areas where small length and time scale physical solutions occur. 


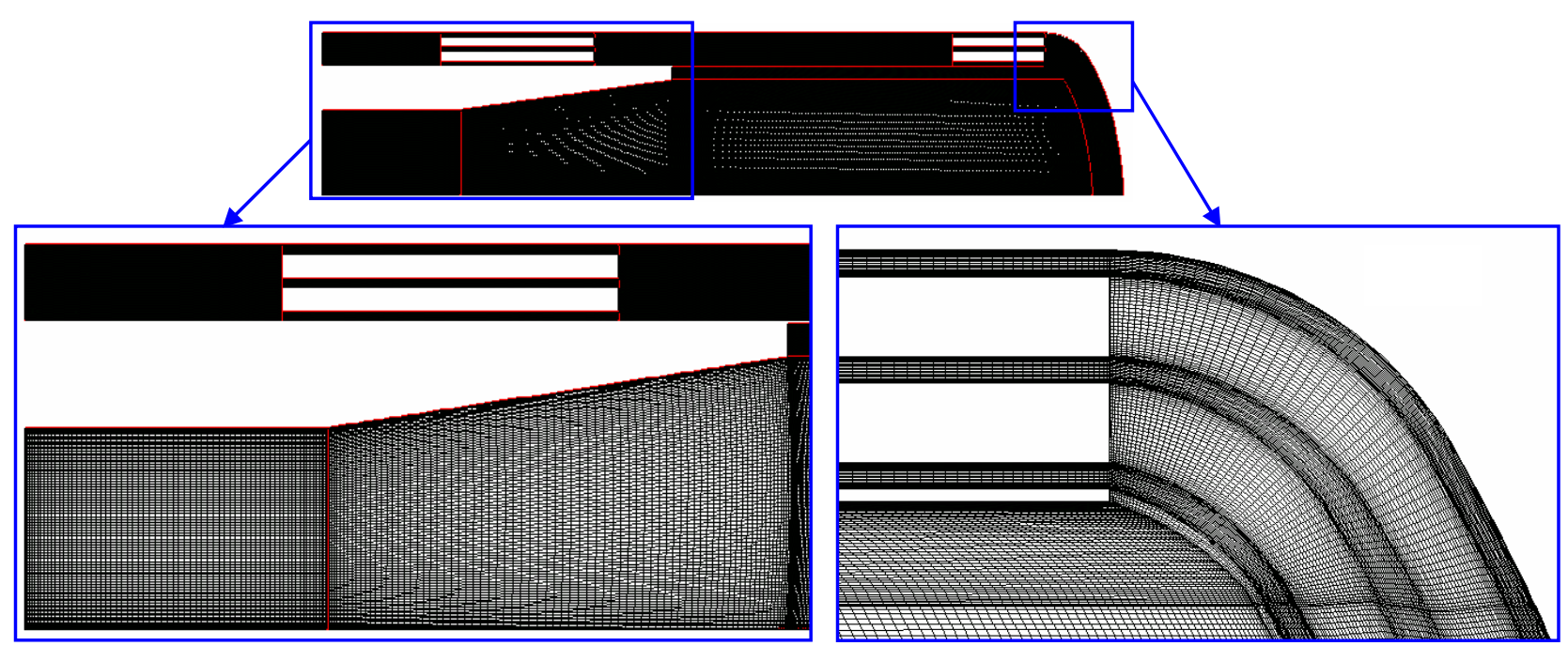

Figure 10.-Model 3.0 Mesh. The mesh independence study identified the most appropriate mesh to use for the data tracking effort.

\section{E. Data Tracking}

The data tracking study was conducted using the optimized mesh and porous-media input parameters (permeability and inertial coefficient) which were identified in the mesh independence study. The first 10 data points for both flow directions, shown in figure 3, were simulated. Figure 11 shows the comparison between CFD and data results of pressure drop for first 10 data points of flow direction 1 (left) and pressure drop for first 10 data points of flow direction 2 (right). The CFD solutions, when compared to the test data, were within 6 percent agreement on average (averaged over percent difference for all simulated data points in data tracking study). The derived constants increased accuracy by 14 percent on average when compared to the same simulations using porousmedia input parameters calculated from oscillating flow test data.
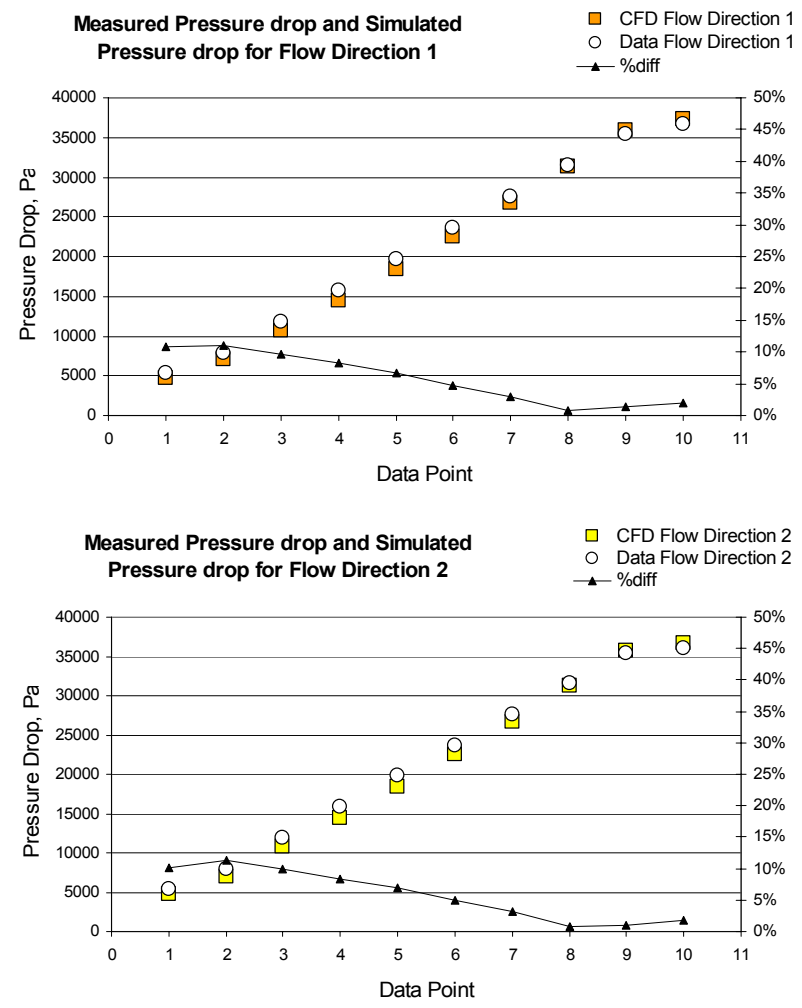

Figure 11.-Data Tracking Results. Comparison between CFD and unidirectional flow test data results of pressure drop for first 10 data points of Flow Direction 1 (left) and pressure drop for first 10 data points of Flow Direction 2 (right). 


\section{Concluding Remarks}

This effort involved reducing TDC heater head unidirectional flow test data, calculating permeability and inertial coefficient, and validating CFD models using the calculated porous-media input parameters. Based on the initial CFD simulation results, the flow test fixture design was revised to include an adjustment to the entrance geometry, an adjustment to the approach annulus radial location, and the addition of a flow distribution screen near the heater head interface. Unidirectional flow testing was completed for air flow through a TDC heater head at NASA. The Darcy-Forchheimer coefficients (permeability and inertial coefficient) were derived from unidirectional flow test data.

CFD models were used to simulate the test section and test conditions. The CFD solutions, when compared to the test data, were within 6 percent agreement on average (averaged over percent difference for all simulated data points). The derived constants increased accuracy by 14 percent on average for CFD predictions of unidirectional laminar flow through the TDC heater head.

The results suggest the permeability and inertial coefficient derived from unidirectional flow data $(K=3.13 \mathrm{E}$ $10, C f=0.124$ ), corresponding to 100 percent data regression function seen in figure 5 , are more appropriate for use in this physical domain. This assumption is limited to the range of regenerator Reynolds numbers explored in this study $(17<\mathrm{Re}<86)$. Gaining confidence in the porous-media input parameters for unidirectional flow simulations instills a high level of confidence for use of said coefficients in multi-D Stirling simulations where quasi-steady flow is assumed for regenerator flows.

\section{References}

1. Thieme, L.G. and Schreiber, J.G., "Advanced Technology Development for Stirling Convertors," in proceedings of Space Technology and Applications International Forum (STAIF 2004), edited by M. El-Genk, AIP Conference Proceedings 654, Melville, New York, pp. 432-439, 2004.

2. Thieme, L.G. and Schreiber, J.G., Supporting Development for the Stirling Radioisotope Generator and Advanced Technology Development at NASA Glenn, NASA/TM-2005-213409.

3. Tew, R.C., Cairelli, J.E., Overview of NASA Multi-Dimensional Stirling Convertor Code Development and Validation Effort, NASA/TM-2002-211997.

4. Tew, R.C., GRC Regenerator Research Grant Milestones \& Draft Non-Equilibrium Porous-Media Model, presented at the Regenerator Research Grant Review at the University of Minnesota, Grant no. NNC04GA04G, June 17th, 2005.

5. Tew, R.C., Written Communication on Sage Simulations for Oscillating Helium in TDC, Internal Memorandum, December 17th, 2004.

6. Gedeon, D., Wood, G., Oscillating-Flow Regenerator Test Rig: Hardware and Theory With Derived Correlations for Screens and Felts, NASA Contractor Report 198442, 1996.

7. Tannehill, Anderson, Pletcher, Computational Fluid Mechanics and Heat Transfer, 2nd Ed., Taylor \& Francis, Philadelphia, PA, 1997.

8. Niu, Y., Simon, T.W., Ibrahim, M.B., Tew, R., and Gedeon, D., "Measurements of Unsteady Convective Heat Transfer Rates within a Stirling Regenerator Matrix Subjected to Oscillatory Flow," in proceedings of 1st International Energy Conversion Engineering Conference, Portsmouth, VA, Paper No. AIAA-2003-6013, 2003a.

9. Niu, Y., Simon, T.W., Ibrahim, M.B., Tew, R., and Gedeon, D., "JET Penetration into a Stirling Engine Regenerator Matrix with Various Regenerator-to-Cooler Spacings," in proceedings of 1st International Energy Conversion Engineering Conference, Portsmouth, VA, Paper No. AIAA-2003-6014, 2003 b.

10. Niu, Y., Simon, T., Gedeon, D. and Ibrahim, M., "On Experimental Evaluation of Eddy Transport and Thermal Dispersion in Stirling Regenerators," in proceedings of 2nd International Energy Conversion Engineering Conference, Paper No. AIAA-2004-5646, Providence, RI, August 15-19, 2004.

11. Fox, R.W., McDonald, A.T., Introduction to Fluid Mechanics, 5th Ed., John Wiley, New York, NY, 1998. 


\section{Appendix}
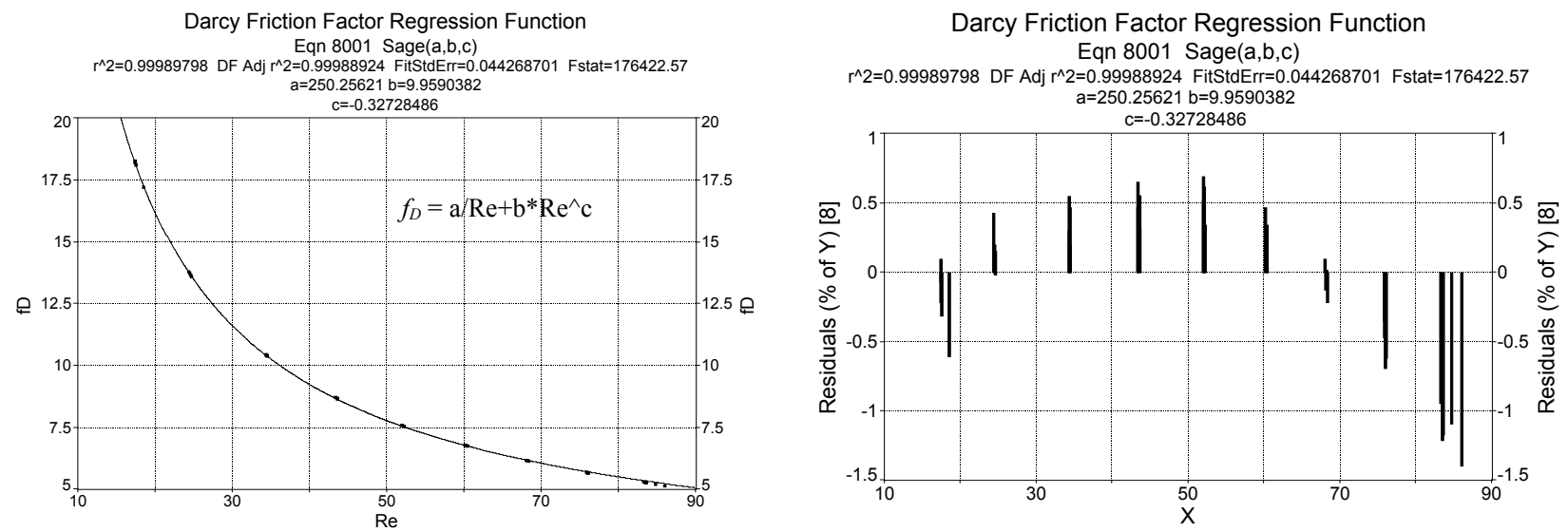

Figure A-1.-Regression function to 100 percent Pressure Drop Measured in Unidirectional Flow Testing. Darcy Friction Factor regression function $\left(\mathrm{f}_{\mathrm{D}}\right.$ ) versus $\mathrm{Re}_{\mathrm{r}}(\mathrm{left})$ and Darcy Friction Factor regression function residuals (right).
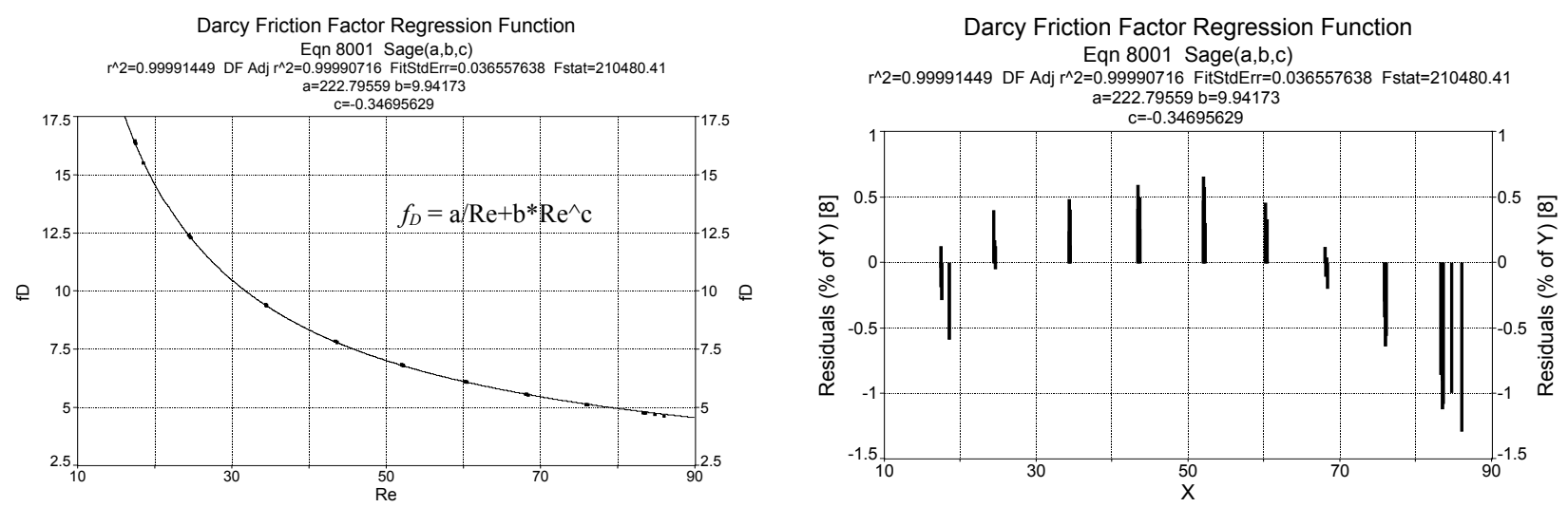

Figure A-2.- Regression function 90.2 percent Pressure Drop Measured in GRC Unidirectional Flow Testing. Darcy Friction Factor regression function ( $\mathrm{f}_{\mathrm{D}}$ ) versus $\mathrm{Re}_{\mathrm{r}}$ (left) and Darcy Friction Factor regression function residuals (right).
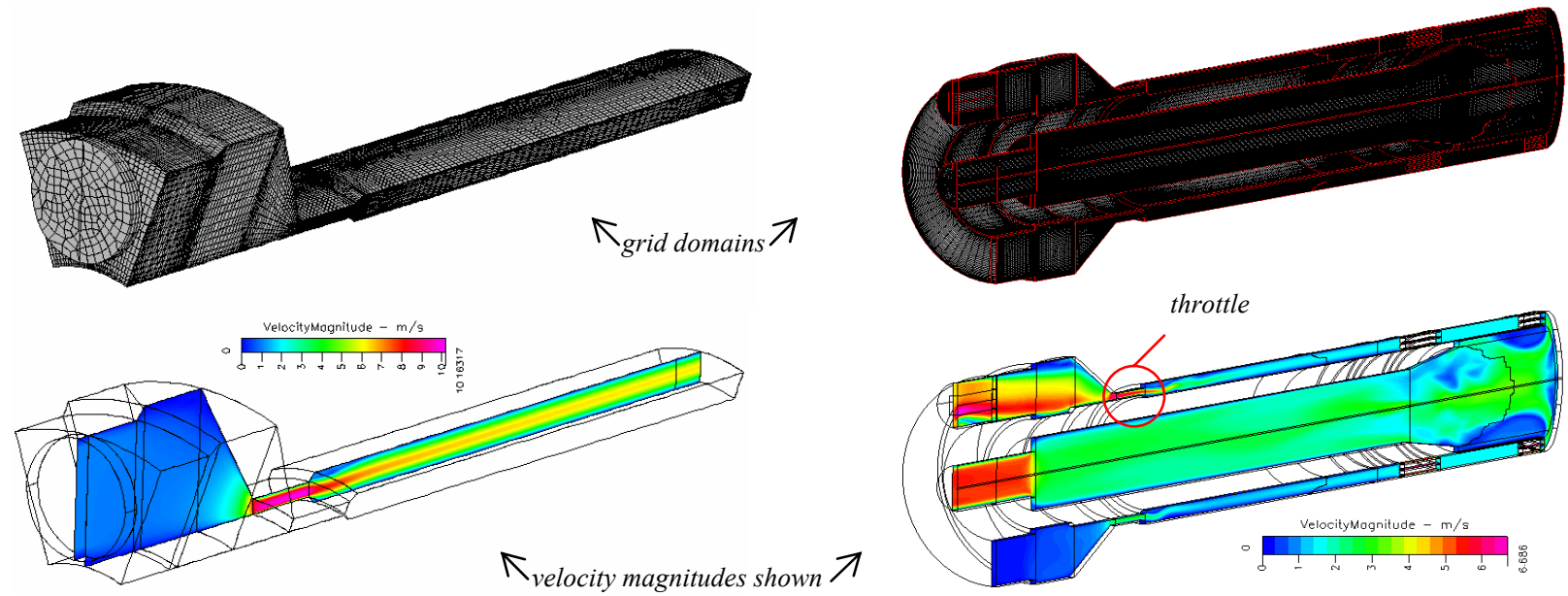

Figure A-3.-3D CFD Models. 3D truncated domain of the entrance region near the off-center port was simulated to confirm improved velocity distribution after geometry revisions were made to test fixture geometry (left) and flow distribution of Model 1 simulated in the Domain Selection section was used to investigate axial and circumferential velocity distribution of the test fixture (right). 
Public reporting burden for this collection of information is estimated to average 1 hour per response, including the time for reviewing instructions, searching existing data sources, gathering and maintaining the data needed, and completing and reviewing the collection of information. Send comments regarding this burden estimate or any other aspect of this collection of information, including suggestions for reducing this burden, to Washington Headquarters Services, Directorate for Information Operations and Reports, 1215 Jefferson Davis Highway, Suite 1204, Arlington, VA 22202-4302, and to the Office of Management and Budget, Paperwork Reduction Project (0704-0188), Washington, DC 20503.

\begin{tabular}{|l|l|l}
\hline 1. AGENCY USE ONLY (Leave blank) & $\begin{array}{c}\text { 2. REPORT DATE } \\
\text { April } 2006\end{array}$ & $\begin{array}{r}\text { 3. REPORT TYPE AND DATES COVERED } \\
\text { Technical Memorandum }\end{array}$ \\
\hline
\end{tabular}

\section{TITLE AND SUBTITLE}

Experimental and Computational Analysis of Unidirectional Flow Through Stirling Engine Heater Head

\section{AUTHOR(S)}

Scott D. Wilson, Rodger W. Dyson, Roy C. Tew, and Rikako Demko

\section{FUNDING NUMBERS}

WBS-22-972-20-01

\section{PERFORMING ORGANIZATION NAME(S) AND ADDRESS(ES)}

National Aeronautics and Space Administration

John H. Glenn Research Center at Lewis Field

Cleveland, Ohio 44135-3191
8. PERFORMING ORGANIZATION REPORT NUMBER

E-15491

\section{SPONSORING/MONITORING AGENCY NAME(S) AND ADDRESS(ES)}

National Aeronautics and Space Administration

Washington, DC 20546-0001
10. SPONSORING/MONITORING AGENCY REPORT NUMBER

NASA TM-2006-214246

AIAA-2005-5539

\section{SUPPLEMENTARY NOTES}

Prepared for the Third International Energy Conversion Engineering Conference sponsored by the American Institute of Aeronautics and Astronautics, San Francisco, California, August 15-18, 2006. Scott D. Wilson and Rikako Demko, Sest, Inc., 18000 Jefferson Park, Suite 104, Middleburg Heights, Ohio 44135; Rodger W. Dyson and Roy C. Tew, NASA Glenn Research Center. Responsible person, Scott D. Wilson, organization code RPT, 216-433-6681.

12a. DISTRIBUTION/AVAILABILITY STATEMENT

12b. DISTRIBUTION CODE

Unclassified - Unlimited

Subject Categories: 20, 34, 44, and 64

Available electronically at http://gltrs.grc.nasa.gov

This publication is available from the NASA Center for AeroSpace Information, 301-621-0390.

13. ABSTRACT (Maximum 200 words)

A high efficiency Stirling Radioisotope Generator (SRG) is being developed for possible use in long-duration space science missions. NASA's advanced technology goals for next generation Stirling convertors include increasing the Carnot efficiency and percent of Carnot efficiency. To help achieve these goals, a multi-dimensional Computational Fluid Dynamics (CFD) code is being developed to numerically model unsteady fluid flow and heat transfer phenomena of the oscillating working gas inside Stirling convertors. In the absence of transient pressure drop data for the zero mean oscillating multi-dimensional flows present in the Technology Demonstration Convertors on test at NASA Glenn Research Center, unidirectional flow pressure drop test data is used to compare against 2D and 3D computational solutions. This study focuses on tracking pressure drop and mass flow rate data for unidirectional flow though a Stirling heater head using a commercial CFD code (CFD-ACE). The commercial CFD code uses a porous-media model which is dependent on permeability and the inertial coefficient present in the linear and nonlinear terms of the Darcy-Forchheimer equation. Permeability and inertial coefficient were calculated from unidirectional flow test data. CFD simulations of the unidirectional flow test were validated using the porous-media model input parameters which increased simulation accuracy by 14 percent on average.

\section{SUBJECT TERMS}

Computational fluid dynamics; Thermodynamics; Stirling engines; Fluid dynamics; Power conversion; Energy loss; Pressure drop testing; Regenerator

\begin{tabular}{|c|c|c|}
\hline $\begin{array}{c}\text { 17. SECURITY CLASSIFICATION } \\
\text { OF REPORT } \\
\text { Unclassified }\end{array}$ & $\begin{array}{c}\text { 18. SECURITY CLASSIFICATION } \\
\text { OF THIS PAGE } \\
\text { Unclassified }\end{array}$ & $\begin{array}{c}\text { 19. SECURITY CLASSIFICATION } \\
\text { OF ABSTRACT } \\
\text { Unclassified }\end{array}$ \\
\hline
\end{tabular}

